\title{
The effects of insulin on the level and activity of the GLUT4 present in human adipose cells
}

\author{
I.J. Kozka ${ }^{1}$, A. E. Clark ${ }^{1}$, J.P.D. Reckless ${ }^{2}$, S. W. Cushman ${ }^{3}$, G. W. Gould ${ }^{4}$, G. D. Holman ${ }^{1}$ \\ ${ }^{1}$ School of Biology and Biochemistry, University of Bath, Bath, UK \\ ${ }^{2}$ School of Postgraduate Medicine, Royal United Hospital, University of Bath, Bath, UK \\ ${ }^{3}$ Experimental Diabetes, Metabolism and Nutrition Section, Diabetes Branch, National Institute of Diabetes and Digestive and \\ Kidney Diseases, National Institutes of Health, Bethesda, Maryland, USA \\ ${ }^{4}$ Department of Biochemistry, University of Glasgow, Glasgow, UK
}

Summary Human adipose cells are much less responsive to insulin stimulation of glucose transport activity than are rat adipocytes. To assess and characterize this difference, we have determined the rates of 3-O-methyl-D-glucose transport in human adipose cells and have compared these with the levels of glucose transporter 4 (GLUT4) assessed by using the bis-mannose photolabel, 2-N-4-(1-azi-2,2,2-trifluoroethyl)benzoyl-1,3-bis-(D-mannos-4-yloxy)-2-propylamine, ATB-BMPA. The rates of 3-O-methyl-Dglucose transport and the cell-surface level of GLUT4 are very similar in the human and rat adipocyte in the basal state. The $\mathrm{V}_{\max }$ for 3-O-methyl-Dglucose transport in fully insulin-stimulated human adipose cells is 15 -fold lower than in rat adipose cells. Photolabelling of GLUT4 suggests that this low transport activity is associated with a low GLUT4 abundance $\left(39 \cdot 10^{4}\right.$ sites/cell; $19.9 \cdot 10^{4}$ sites at the cell surface). The turnover number for human adipose cell GLUT4 $\left(5.8 \cdot 10^{4} \mathrm{~min}^{-1}\right)$ is similar to that observed for GLUT4 in rat adipose cells and the mouse cell line, 3T3L1. Since $50 \%$ of the GLUT4 is at the cell surface of both human and rat adipose cells in the fully insulin-stimulated state, an inefficient GLUT4 exocytosis process cannot account for the low transport activity. The intracellular retention process appears to have adapted to release, in the basal state, a greater proportion of the total-cellular pool of GLUT4 to the cell surface of the larger human adipocytes. These cell-surface transporters are presumably necessary to provide the basal metabolic needs of the adipocyte. As a consequence of this adaptation to cell size and surface area, the residual intracellular-reserve pool of GLUT4 that is available to respond to insulin is lower in the human than in the rat adipocyte. [Diabetologia (1995) 38: 661-666]

Key words Glucose transport, human adipocytes, photolabelling.
In isolated rat adipose cells, glucose transporter isoform 4 (GLUT4) constitutes approximately $90 \%$ of the total cellular glucose transporter, the remaining portion being GLUT1 [1-3]. Immunocytochemical

Received: 6 June 1994 and in revised form: 4 January 1995

Corresponding author: Dr. G. D. Holman, Department of Biochemistry, University of Bath, Claverton Down, Bath BA2 $7 \mathrm{AY}, \mathrm{UK}$

Abbreviations: GLUT, Glucose transporter isoform; ATBBMPA, 2-N-(4-(1-azi-2,2,2-trifluoroethyl)benzoyl)-1,3-bis-(Dmannos-4-yloxy)-2-propylamine; BMI, body mass index; SDS-PAGE, sodium dodecylsulphate polyacrylamide gel electrophoresis; $\mathrm{C}_{12} \mathrm{E}_{9}$, nonaethyleneglycol dodecylether. studies on brown [4] and white [5] adipose cells and studies utilizing the cell-impermeant photoaffinity compound, 2-N-(4-(1-azi-2,2,2,-trifluoroethyl)benzoyl) - 1,3 - bis - (D-mannos-4-yloxy) - 2 - propylamine (ATB-BMPA) in white rat adipose cells $[2,6]$, have suggested that very little of the cellular GLUT4 is present at the cell surface in the absence of insulin. Following insulin stimulation, the intracellular GLUT4 is rapidly translocated to the cell surface where its level is increased by approximately 20 -fold compared with basal cells [4-6]. The GLUT4 isoform also appears to be the principal glucose transporter isoform in human adipose cells and is thought to be responsible for mediating the major portion of the insulin-stimulated glucose transport in these cells [7-9]. 
Pedersen and Gliemann [10] showed that the increase in glucose transport activity that is attainable on insulin stimulation of human adipose cells is much less than in rat adipose cells. To further characterize this difference, we have compared the 3-O-methyl-D-glucose transport activity with the levels of cell-surface GLUT4 as determined by photolabelling with the ATB-BMPA photolabel. Studies on GLUT1 and GLUT4 present in 3T3-L1 cells [11] and expressed in Xenopus oocytes [12] have shown that this approach can be used to assess both the number of cell-surface transporters and also their catalytic turnover.

\section{Materials and methods}

Materials. 3-O-methyl-D-[U $\left.-{ }^{14} \mathrm{C}\right]$-glucose was from Amersham International, Little Chalfont, Bucks., UK. ATB-[2- $\left.{ }^{3} \mathrm{H}\right]-$ BMPA was synthesised as described previously [13]. Collagenase was from Worthington, Freehold, N. J., USA. Bovine serum albumin was from Sigma, Poole, Dorset, UK and was extensively dialysed and filtered. Insulin was kindly provided by Dr. R. Chance, Eli Lilly, Indianapolis, Ind., USA. Nonaethyleneglycol dodecylether $\left(\mathrm{C}_{12} \mathrm{E}_{9}\right)$ was from Boehringer, Lewes, East Sussex, UK.

Patients and adipose tissue. Specimens of human subcutaneous adipose tissue were obtained, with consent, from the abdominal region of female patients undergoing elective gynaecological surgery. The patients were from 20 to 50 years of age, their body mass index (BMI) was $26 \pm 1 \mathrm{~kg} / \mathrm{m}^{2}$, and none suffered from endocrine disorders. For comparison with the female tissue, one specimen was also obtained from a 51-year-old male patient (BMI $23.5 \mathrm{~kg} / \mathrm{m}^{2}$ ) undergoing gastroenterological surgery. The patients were fasted for about $12 \mathrm{~h}$. General anaesthesia was induced with a short-acting barbiturate and was maintained with a mixture of halothane, nitrous oxide and oxygen. For each experiment 10-30 g of specimen tissue was excised at the beginning of surgery and placed in HEPES buffer [(in mmol/l) $140 \mathrm{NaCl}, 4.7 \mathrm{KCl}, 1.25 \mathrm{Mg}_{2} \mathrm{SO}_{4}, 2.5 \mathrm{CaCl}_{2}, 2.5$ $\left.\mathrm{NaH}_{2} \mathrm{PO}_{4}, 10 \mathrm{HEPES}, \mathrm{pH} 7.4\right]$ and containing $5 \mathrm{mmol} / \mathrm{l}$ glucose and $1 \%$ albumin. The tissue was transported to the laboratory in a thermos flask within 15-30 min.

Preparation of adipose cells and membranes. Adipose cells were prepared according to the methods previously described for rat [14-16] and human adipose cells $[17,18]$. The tissue was cut into small fragments free of connective tissue and clotted blood. About $2 \mathrm{~g}$ of tissue was placed in $25 \mathrm{ml}$ polystyrene tubes containing $3.5 \mathrm{ml}$ of $4 \%$ albumin in HEPES buffer supplemented with $5 \mathrm{mmol} / \mathrm{l}$ glucose and containing $0.7 \mathrm{mg} / \mathrm{ml}$ collagenase. The tissue was minced with fine scissors and the adipocytes were isolated by incubation for approximately $30 \mathrm{~min}$ at $37^{\circ} \mathrm{C}$ with shaking. The cell suspension was filtered through a nylon mesh with a pore size of $400 \mu \mathrm{m}$. The cells were washed four times in the $4 \%$ albumin/HEPES buffer without glucose and finally resuspended at $40 \%$ cytocrit. Cells were then incubated in the absence or presence of $20 \mathrm{nmol} / \mathrm{lin}$ sulin for $40 \mathrm{~min}$ at $37^{\circ} \mathrm{C}$ and further subjected to either transport or ATB-BMPA labelling assays. Membrane fractions were isolated following homogenization and differential centrifugation as described previously [16].

Transport activity assays in human adipose cells. Glucose transport activity was determined by measuring the initial rates of uptake of $50 \mu \mathrm{mol} / 13$-O-methyl-D-glucose at $37^{\circ} \mathrm{C}$, as previously described for the isolated rat adipose cells [14-16]. Briefly, $50 \mu \mathrm{l}$ of adipose cells at $40 \%$ cytocrit were rapidly pipetted into $10 \mu \mathrm{l}$ HEPES buffer containing 3-O-methyl-D-[U${ }^{14} \mathrm{Cl}$-glucose and unlabelled 3-O-methyl-D-glucose to give a final substrate concentration of $50 \mu \mathrm{mol} / \mathrm{l}$. The transport rates were slow compared with rat adipose cells and consequently longer uptake times were required for determination of rate constants. At appropriate times, usually 30 or $90 \mathrm{~s}$ for basal cells and $30 \mathrm{~s}$ for insulin-stimulated cells, the glucose uptake was terminated by the addition of $3 \mathrm{ml}$ of HEPES buffer containing $0.3 \mathrm{mmol} / \mathrm{l}$ phloretin. The cell-associated radioactivity was determined in the cells recovered after centrifugation through an approximately $0.5 \mathrm{ml}$ layer of silicone oil. The uptake at these times was compared with the equilibrium filling of the cells at $5 \mathrm{~min}$ and from these fractional fillings the uptake rate constants were determined as described previously [14]. The equilibrated radioactivity associated with the cells was also used to calculate the intracellular water space by using the estimate of $8 \cdot 10^{5}$ cells per $\mathrm{ml}$ of $40 \%$ cells [17]. For the kinetic studies, the competing sugars were placed together with the radioactive tracer at the bottom of the tube in a final volume of $20 \mu \mathrm{l}$, into which $50 \mu \mathrm{l}$ of cells were pipetted. In the experiments in which ATB-BMPA was used as a transport inhibitor, the cells were first preincubated with the compound for $5 \mathrm{~min}$. A $50-\mu \mathrm{l}$ aliquot of cells was then withdrawn and pipetted into the radioactive sugar mixture.

ATB-BMPA photolabelling of glucose transporters in human adipose cells. Following stimulation with insulin, and where appropriate a $5-\mathrm{min}$ preincubation with the competing sugars, $1 \mathrm{ml}$ of cells in $4 \%$ albumin in HEPES buffer was added to $500 \mu \mathrm{Ci}$ of ATB- $\left[2{ }^{3} \mathrm{H}\right]-\mathrm{BMPA}$ in $0.5 \mathrm{ml}$ of HEPES buffer in 35 - $\mathrm{mm}$ polystyrene dishes and irradiated for $1 \mathrm{~min}$ in a Rayonet photochemical reactor as described previously $[2,19]$. Following irradiation the cells were rapidly washed three times with $1 \%$ albumin in HEPES buffer at $18^{\circ} \mathrm{C}$ and solubilized in $1 \mathrm{ml}$ of detergent buffer containing $2 \% \mathrm{C}_{12} \mathrm{E}_{9}$ in $5 \mathrm{mmol} / 1$ sodium phosphate buffer at $\mathrm{pH} 7.2$ and with the proteinase inhibitors antipain, aprotinin, leupeptin, pepstatin $A$, each at $1 \mu \mathrm{g} / \mathrm{ml}$. To estimate the levels of the transporters present in the total cellular pool, cells were permeabilized with $0.025 \%$ digitonin in the presence of $500 \mu \mathrm{Ci}$ ATB-[2- $\left.{ }^{3} \mathrm{H}\right]$-BMPA for $10 \mathrm{~min}$ at $18^{\circ} \mathrm{C}$ and then irradiated $[20,21]$. These cells were then, without washing, directly solubilized in $2 \mathrm{ml}$ of detergent buffer. For all samples, the non-solubilized material was removed by centrifugation at $20,000 \cdot g$ for $20 \mathrm{~min}$.

Immunoprecipitation and Western blotting of GLUT4. Rabbit antisera against the GLUT1 and GLUT4 glucose transporters were prepared using synthetic C-terminal peptides as described previously $[2,13]$. To immunoprecipitate the photolabelled transporters, $100 \mu \mathrm{l}$ of each antiserum was conjugated to $20 \mu \mathrm{l}$ of protein A-sepharose by mixing for $2 \mathrm{~h}$ in $5 \mathrm{mmol} / \mathrm{l}$ phosphate buffer at $0-4^{\circ} \mathrm{C}$. The conjugates were washed with $5 \mathrm{mmol} / \mathrm{l}$ phosphate buffer. The solubilized cell material in detergent buffer was then added to the antiserum-protein A conjugates and mixed at $0-4^{\circ} \mathrm{C}$ for $2 \mathrm{~h}$ with the appropriate antibody. In most cases, the first immunoprecipitation was with anti-GLUT4 antiserum and this was followed by the immunoprecipitation with anti-GLUT1 antiserum. In each case the immunopellets were washed four times with $1 \mathrm{ml}$ of the detergent buffer containing $1 \% \mathrm{C}_{12} \mathrm{E}_{9}$ and once with detergent free buffer. Finally, the labelled proteins were released from the conjugates with electrophoresis buffer containing $10 \%(\mathrm{w} / \mathrm{v})$ sodium docecylsulphate (SDS), 6 $\mathrm{mol} / \mathrm{l}$ urea and $10 \%(\mathrm{v} / \mathrm{v})$ mercaptoethanol. The proteins 
were resolved on $7 \%$ SDS-PAGE and gel lanes were then separated and sliced. The radioactivity in the gel slices was extracted as previously described [2]. For Western blotting, proteins were transferred onto nitrocellulose membranes. The membranes were blocked with $3 \%$ albumin in $154 \mathrm{mmol} / 1$ $\mathrm{NaCl}, 10 \mathrm{mmol} / \mathrm{l}$ TRIS-HCl, pH 7.4 containing $0.1 \%$ Tween and incubated in the same buffer but containing $1 \%$ albumin with affinity purified GLUT4 antibody $(4 \mu \mathrm{g}$ in $10 \mathrm{ml})$. The bound antibody was localized by incubation with ${ }^{125}$ I-proteinA and autoradiography.

\section{Results}

Glucose transport activity in human adipose cells. Insulin stimulation typically led to an approximately 3fold increase in the rate constant for uptake of a non-saturating $50 \mu \mathrm{mol} / 1$ concentration of 3-O-methyl-D-glucose into human adipose cells (from $0.32 \pm$ $0.04 \mathrm{~min}^{-1}$ to $0.96 \pm 0.07 \mathrm{~min}^{-1}$; from 15 experiments). At equilibrium, $50 \mu \mathrm{mol} / 1$ 3-O-methyl-D-[U${ }^{14} \mathrm{C}$-glucose distributed into an intracellular volume of $2.9 \pm 0.2 \mu \mathrm{l} / 10^{6}$ cells. To determine the kinetic characteristics of 3-O-methyl-D-glucose transport in the insulin-stimulated state for comparison with the results from photolabelling the cell surface GLUT4, the initial rates of uptake of $3-\mathrm{O}$-methyl-[U- $\left.{ }^{14} \mathrm{C}\right]-\mathrm{D}-$ glucose in the presence of increasing concentrations of unlabelled 3-O-methyl-D-glucose were determined. Figure 1 shows a single experiment in basal cells, with $\mathrm{K}_{\mathrm{m}}$ of $3.6 \mathrm{mmol} / \mathrm{l}$ and $\mathrm{V}_{\max }$ of $0.8 \mathrm{mmol} / \mathrm{l}$ $\mathrm{min}^{-1}$, and a representative experiment from three experiments on insulin-treated cells. In the insulinstimulated state, the $K_{m}$ and $V_{\max }$ values are $4.7 \pm$ $1.1 \cdot \mathrm{mmol} / 1$ and $3.3 \pm 0.8 \mathrm{mmol} / 1 \cdot \mathrm{min}^{-1}$ (from three experiments). These results are consistent with those of Pedersen and Gliemann [10] who showed that insulin does not markedly alter the $\mathrm{K}_{\mathrm{m}}$ for 3-O-methyl-D-glucose transport activity in human adipose cells.

Previous studies on rat adipose cells have shown that the affinity of GLUT4 for ATB-BMPA is approximately $200 \mu \mathrm{mol} / 1[2,11]$. In human adipocytes, ATB-BMPA inhibits 3-O-methyl-D-glucose transport with a $K_{\mathrm{i}}$ of approximately $200 \mu \mathrm{mol} / \mathrm{l}$ both in the basal and insulin-stimulated states (Fig. 2).

ATB-BMPA labelling of cell-surface and total-cellular GLUT4 and GLUT1. To assess the cell-surface levels of GLUT4 and GLUT1, these transporters were labelled in intact human adipose cells with the ATB- $\left[2-{ }^{3} \mathrm{H}\right]-B M P A$. The labelled transporters were immunoprecipitated and resolved on SDS-PAGE. A representative gel profile of the immunoprecipitated GLUT4 is shown in Figure 3. Insulin increased the cell-surface exposure of GLUT4 to the impermeant photolabel by $2-3$-fold. Both GLUT4 and GLUT1 isoforms were labelled by ATB-BMPA. However, the cell-surface level of GLUT1 was less than $10 \%$

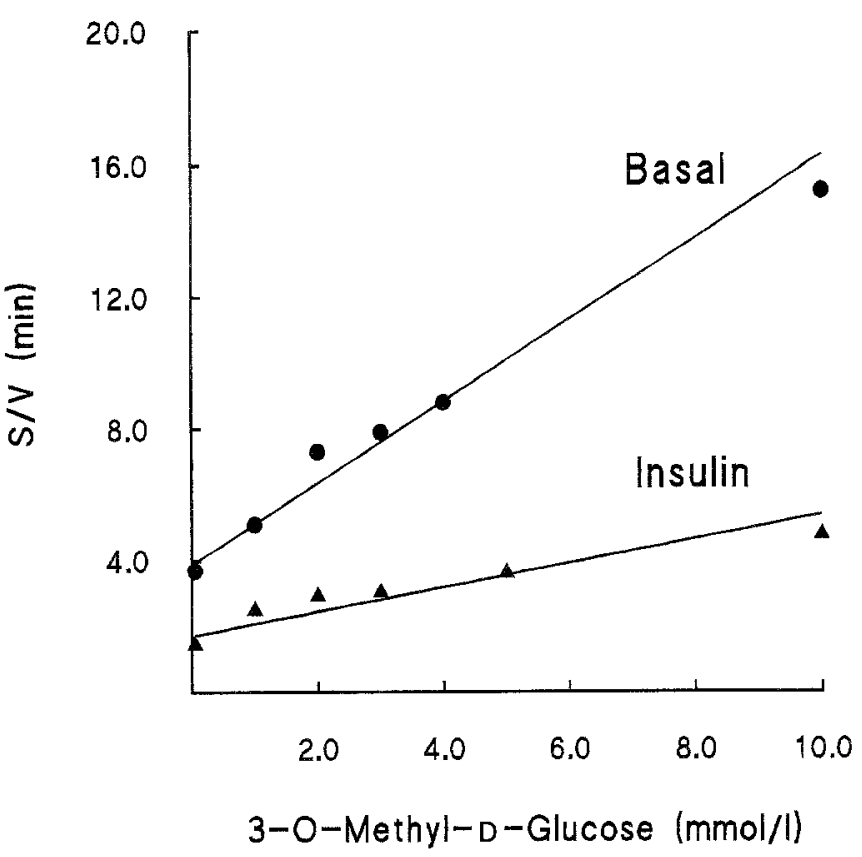

Fig. 1 Kinetic analysis of 3-O-methyl-D-glucose transport in human adipose cells. The initial rates of net uptake of 3-O-methyl-[U- $\left.{ }^{14} \mathrm{C}\right]$-D-glucose at the indicated concentrations were determined in human adipose cells either in the basal state (•) or the insulin-stimulated state $(\boldsymbol{A})$. The results shown are from a single experiment (basal) and a representative experiment from three experiments (insulin). The $\mathrm{K}_{\mathrm{m}}$ and $\mathrm{V}_{\max }$ were determined by fitting the Michaelis-Menten equation by nonlinear regression (weighted for relative error)

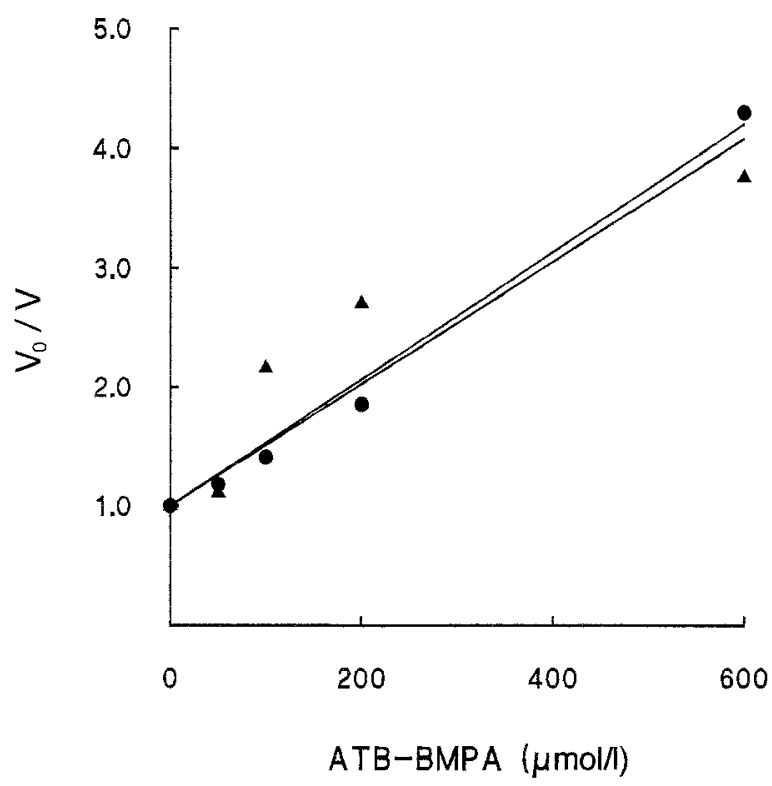

Fig. 2 Inhibition of 3-O-methyl-D-glucose by ATB-BMPA. Human adipose cells were incubated in the absence $(\bullet)$ or presence $(\mathbf{A})$ of insulin and then the initial rates of uptake of $50 \mu \mathrm{mol} / 1$ 3-O-methyl-D- $\left[\mathrm{U}-{ }^{14} \mathrm{C}\right]$-glucose were determined in the absence $\left(\mathrm{v}_{\mathrm{o}}\right)$ or presence $(\mathrm{v})$ of the indicated concentration of ATB-BMPA. The data points shown are the means from two separate experiments 


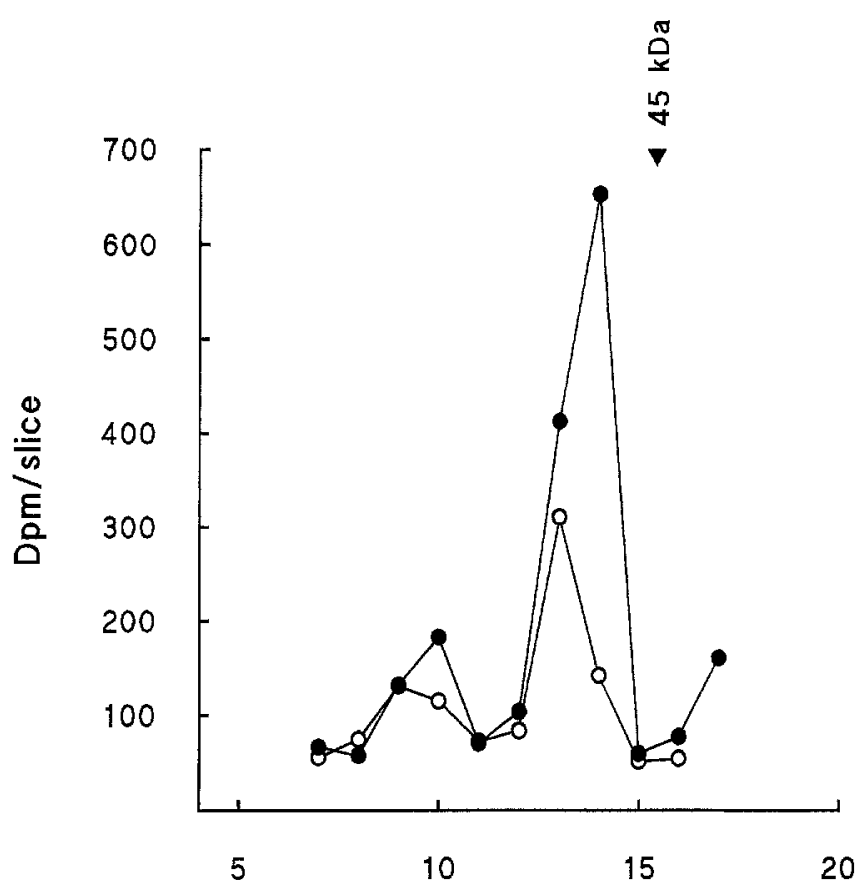

Gel slice number

Fig.3 ATB-BMPA photolabelling of the cell-surface GLUT4 present in human adipose cells. 1-ml suspensions of human adipose cells treated either with (•) or without (o) $20 \mathrm{nmol} / 1 \mathrm{insu}-$ lin for $40 \mathrm{~min}$ at $37^{\circ} \mathrm{C}$ were photolabelled by irradiation for $1 \mathrm{~min}$ in the presence of $500 \mu \mathrm{Ci}$ of ATB-[2- $\left.{ }^{3} \mathrm{H}\right]-\mathrm{BMPA}$. The cells were washed in $1 \%$ albumin/HEPES buffer and solubilized in $\mathrm{C}_{12} \mathrm{E}_{9}$ detergent buffer as described in "Methods". Photolabelled material was immunoprecipitated by antiGLUT4-C-terminal peptide antiserum and was then analysed by SDS-PAGE

of that of GLUT4 and no attempt was made to quantify the insulin responsiveness of this isoform.

Figure 4 shows the results from a series of experiments in which the levels of GLUT4 at the cell surface were compared with the total cellular levels. The total cellular GLUT4 was estimated by labelling the transporters in the presence of digitonin, a compound which permeabilizes the cells, thereby allowing the normally impermeant ATB-BMPA access to the intracellular transporter stores [20,21]. Labelling in the digitonin-treated cells also suggested that GLUT4 was much more abundant than GLUT1 and constituted more than $80 \%$ of the total cellular glucose transporter pool. In this series of experiments, the proportion of GLUT4 at the cell-surface was $27.2 \pm 3.5 \%$ in the basal state and increased to $57.7 \pm 6.6 \%$ in the insulin-stimulated state. Figure 4 also shows that the inclusion of $100 \mathrm{mmol} / \mathrm{l} 3-\mathrm{O}$-methyl-D-glucose reduced the level of surface labelling of GLUT4 by $82 \%$ and the labelling of the total cellular pool by $74 \%$ of the respective controls.

We have to confirmed that the digitonin permeabilization procedure gives a reliable estimate of the proportion of GLUT4 at the cell surface by Western

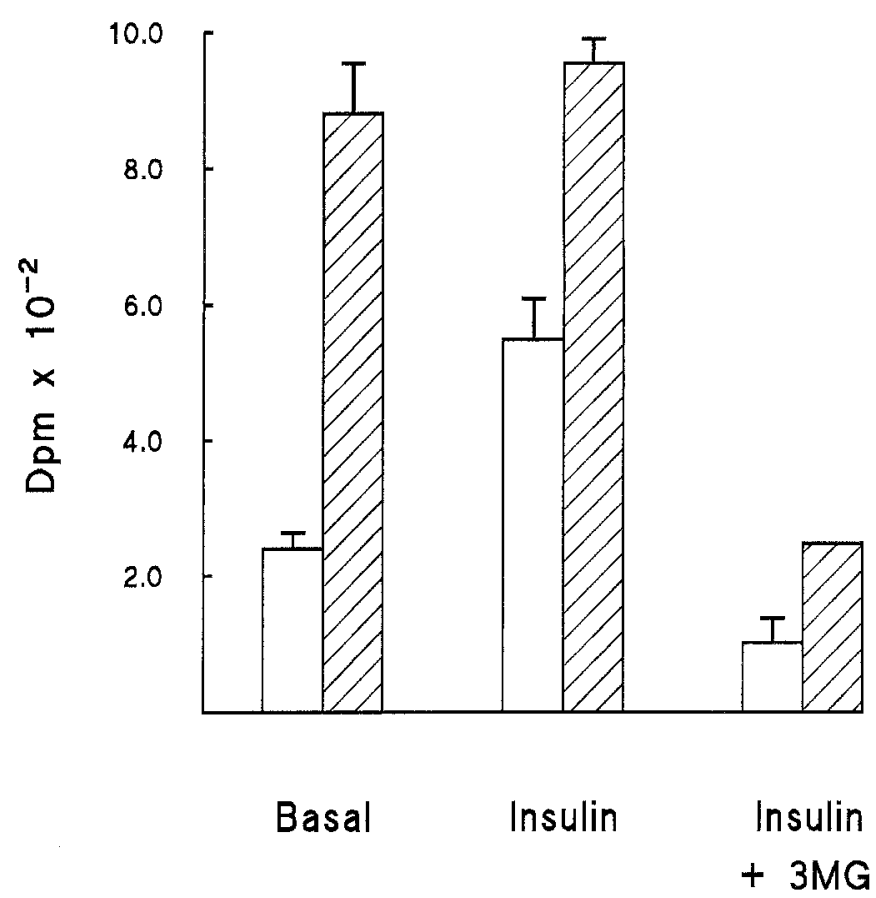

Fig. 4 Distribution of GLUT4 in human adipose cells. The photolabelling of GLUT4 in human adipose cells in the basal and insulin-stimulated states was carried out in the presence $(\square)$ and absence $(\square)$ of $0.025 \%$ digitonin (which allows the normally impermeant reagent access to the intracellularly located glucose transporters). The results show the mean \pm SEM from 4-9 separate experiments. The ability of $100 \mathrm{mmol} / \mathrm{l}$ 3-O-methyl-D-glucose to compete with the ATBBMPA in the photolabelling reaction is also shown ( $+3 \mathrm{MG})$

blotting of plasma membrane and total cellular membranes from insulin-treated cells. Figure 5 shows that the level of GLUT4 is approximately the same in plasma membrane and totalcellular membrane samples. When expressed as a percentage of the total membranes recovered these Western blot data show that approximately $50 \%$ of the GLUT4 is at the cell surface of insulin-stimulated rat and human adipocytes.

If we convert the observed level of labelling by ATB-BMPA from dpm (Fig.4) into moles of label bound then we can use the equilibrium affinity constant to obtain a value for the number of GLUT4 molecules at the cell surface $\left(\mathrm{B}_{\max }\right)$ according to Equation 1:

$\mathrm{B}_{\max }=\frac{\mathrm{B} \cdot\left(\mathrm{K}_{\mathrm{D}}+\mathrm{F}\right)}{\mathrm{F}}$ Eqn. 1

where $F$ is the free ATB-BMPA concentration $(46 \mu \mathrm{mol} / 1), K_{D}$ is the affinity constant $(200 \mu \mathrm{mol} / 1)$ and $B$ and $B_{\max }$ are the moles of ATB-BMPA bound. $\mathrm{B}$ and $\mathrm{B}_{\max }$ can be expressed either in moles/cell or this unit can be converted to $\mu \mathrm{mol} / 1$ using the intracellular water space of $2.9 \mu 1 / 10^{6}$ cells. In the basal state the cell surface level of GLUT4 was found to be 72 fmoles $/ 10^{6}$ cells or $24 \mathrm{nmol} / 1$ corresponding to 4.3 . 
$10^{4}$ sites/cell. In the insulin-stimulated state the cell surface GLUT4 was $165 \mathrm{fmol} / 10^{6}$ cells or $57 \mathrm{nmol} / 1$ corresponding to $9.9 \cdot 10^{4}$ surface sites/cell $\left(39 \cdot 10^{4}\right.$ sites/cell). As the $\mathrm{V}_{\max }$ for transport is expressed as $\mathrm{mmol} / 1 \cdot \mathrm{min}^{-1}$, the catalytic turnover number $(\mathrm{TN})$ can be obtained by dividing the $\mathrm{V}_{\max }$ by the concentration of GLUT4 according to Equation 2:

$\mathrm{TN}=\frac{\mathrm{V}_{\max }}{[\mathrm{GLUT4}]}$

Comparing the $\mathrm{V}_{\max }$ for insulin-stimulated transport with the concentration of GLUT4 at the cell surface gives a catalytic turnover number of $5.8 \cdot 10^{4} \mathrm{~min}^{-1}$ at $37^{\circ} \mathrm{C}$.

\section{Discussion}

In human adipose cells, the glucose transport activity in the basal state is similar to that observed in rat adipose cells [14]. However, there is a major difference in the $V_{\max }$ in these systems following insulin treatment. The $V_{\max }$ for 3-O-methyl-D-glucose is approximately 15-fold lower in human (this study) than in rat adipose cells [14]. We have assessed here whether the low transport activity in fully insulin-stimulated human adipose cells can be attributed to a low abundance of GLUT4 at the cell surface.Application of the ATB-BMPA photolabelling procedure has shown that this effect is mainly due to a low abundance of GLUT4 at the cell surface in the insulin-stimulated state, there being $9.9 \cdot 10^{4}$ sites/human adipose cell present in the plasma membrane. Using a cytochalasin B binding procedure, Simpson et al. [16] showed that in the plasma membrane of rat adipose cells there were $195 \cdot 10^{4}$ cell-surface sites per cell.

The turnover number of GLUT4 in human adipose cells has not been previously estimated but several estimates of the turnover numbers of rodent GLUT4 have been determined. Using cytochalasin $B$ binding data the estimated catalytic turnover of GLUT4 in rat adipose cells is $5.6 \cdot 10^{4} \cdot \mathrm{min}^{-1}$ at $37^{\circ} \mathrm{C}[16]$. Using the ATB-BMPA photolabelling procedure to determine GLUT4 activity in the mouse 3T3-L1 cell line we have calculated a catalytic turnover of $7.9 \cdot 10^{4} \cdot \mathrm{min}^{-1}$ at $37^{\circ} \mathrm{C}$ [11]. A much lower value for the turnover of rat GLUT4 expressed in oocytes has been obtained $\left(1.7 \cdot 10^{4} \cdot \mathrm{min}^{-1}\right)$ at $22^{\circ} \mathrm{C}$ [12]. The catalytic turnover of the GLUT4 would be expected to increase by about three-fold for a $15^{\circ} \mathrm{C}$ rise in temperature [22]. There are clearly many assumptions involved in using the ATB-BMPA photolabel to calculate the turnover number $[11,12]$ but the turnover calculated from application of this technique in human adipose cells $\left(5.8 \cdot 10^{4} \cdot \mathrm{min}^{-1}\right)$ is strikingly similar to values obtained using other techniques and other cell types.

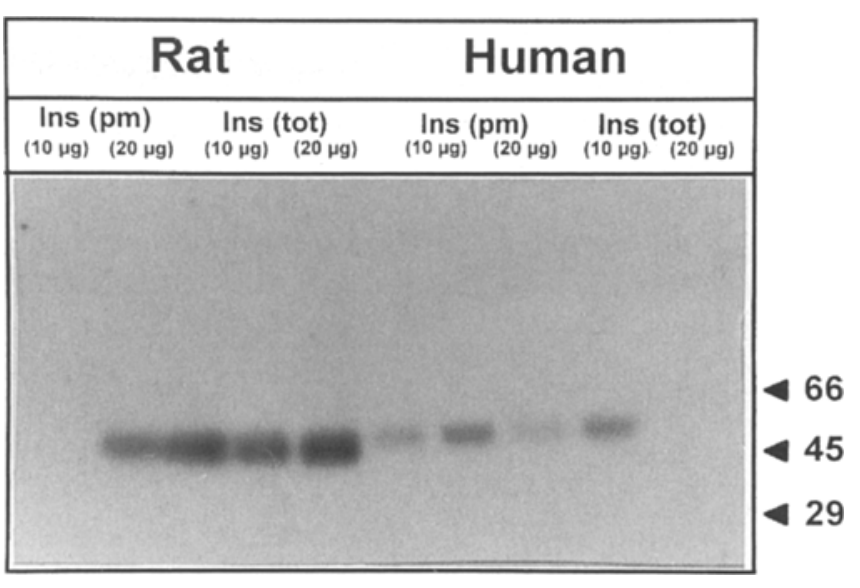

Fig. 5 Western blot analysis of the effect of insulin on the distribution of GLUT4 between the plasma membrane and the total-cellular membrane pool. Membranes were isolated from human and rat adipocytes following homogenization and differential centrifugation and proteins were resolved by SDSPAGE. GLUT4 was detected using affinity purified antibody raised against a synthetic GLUT4 C-terminal peptide. Results are from an experiment representative of three separate experiments

As approximately half of the cellular GLUT4 is at the cell surface of both human and rat adipose cells in the insulin-stimulated state (Figs. 4, 5) [6], the insulin-stimulated exocytosis process for GLUT4 seems to be equally efficient in these systems. Since in the basal state, a higher proportion of the total cell GLUT4 is at the surface (approximately $25 \%$ ) than in rat adipocytes (where only approximately $2 \%$ is at the surface) it appears that the GLUT4 sequestration and retention process $[6,23]$ is inefficient in human adipose cells. However, the cell surface levels of GLUT4 and the $\mathrm{V}_{\max }$ for 3-O-methyl-D-glucose are very similar in the human and rat adipocytes in the basal state $\left[10,14\right.$ and present study]. The basal $V_{\max }$ is presumably sufficient to provide the basal metabolic needs of the adipocyte. It therefore seems likely that in the basal state, the intracellular retention process has adapted to release a greater proportion of the lower total cellular pool of GLUT4 to the cell surface of human adipose cells. As a consequence of this adaptation to cell size and surface area, the residual intracellular-reserve pool of GLUT4 that is available to respond to insulin is lower in the human than in the rat adipocyte. A similar mechanism has been proposed for the adaptation of rat adipose cells to increased cell size. In large rat adipose cells, a depleted intracellular pool of transporters is associated with a greater proportion of the available transporters being distributed to the cell surface [24].

Levels of GLUT1 that are detected in human adipose cells using the photolabelling procedure are only about $10 \%$ of the GLUT4 levels and are not easily resolved from the background on SDS-gels. Because of the low abundance of GLUT1 and because 
this transporter has low affinity for substrate $[11,25]$, GLUT1 will only make a very minor contribution to the 3-O-methyl-D-glucose transport activities of human fat cells.

The regulation of cell surface glucose transporter levels and activity in rat adipose cells has been shown to vary depending upon factors such as the age and size of the animal and the distribution of the fat reserve [24]. Further studies on glucose transporters in human adipose cells aimed at addressing these issues could therefore be carried out using the photolabelling procedure described here.

Acknowledgements. We are grateful to the Medical Research Council (UK) for grant support and thank the surgeons and nursing staff of the Royal United Hospital, Bath, UK, for their generous help.

\section{References}

1. Zorzano A, Wilkinson W, Kotiar G, Thoidis G, Wadzinski BE, Ruoho AE, Pilch PF (1989) Insulin-regulated glucose uptake in rat adipocytes is mediated by two transporter isoforms present in at least two vesicle populations. J Biol Chem 264: 12358-12363

2. Holman GD, Kozka IJ, Clark AE et al. (1990) Cell surface labelling of glucose transporter isoform GLUT4 by bismannose photolabel. Correlation with stimulation of glucose transport in rat adipose cells by insulin and phorbol ester. J Biol Chem 265: 18172-18179

3. Birnbaum MJ (1992) The insulin-sensitive glucose transporter. Int Rev Cytol 137A:239-289

4. Slot JW, Geuze HJ, Gigengack S, Lienhard GE, James DE (1991) Immunolocalization of the insulin regulatable glucose transporter in brown adipose tissue of the rat. J Cell Biol 113: 123-135

5. Smith RM, Charron MJ, Shah N, Lodish HF, Jarett L (1991) Immunoelectron microscopic demonstration of insulin stimulated translocation of glucose transporters to the plasma membrane of isolated rat adipocytes and masking of the carboxy terminal epitope of intracellular GLUT4. Proc Natl Acad Sci USA 88: 6893-6897

6. Satoh S, Nishimura H, Clark AE et al. (1993) Use of bismannose photolabel to elucidate insulin-regulated GLUT4 subcellular trafficking kinetics in rat adipose cells: evidence that exocytosis is the critical site of hormone action. J Biol Chem 269: 17820-17829

7. Pilch PF, Wilkinson W, Garvey, WT, Ciaraldi TP, Hueckstaedt TP, Olefsky JM (1993) Insulin responsive human adipocytes express two glucose transporter isoforms and target them to different vesicles. J Clin Endocrinol Metab 77: $286-289$

8. Garvey WT, Huecksteadt TP, Matthaei S, Olefsky JM (1988) Role of glucose transporters in the cellular insulin resistance of type II non-insulin-dependent diabetes mellitus. J Clin Invest 81: 1528-1536
9. Garvey WT (1992) Glucose transport and NIDDM. Diabetes Care 15: 396-417

10. Pedersen O, Gliemann J (1981) Hexose transport in human adipocytes: factors influencing the response to insulin and kinetics of methylglucose and glucose transport. Diabetologia 20: 630-635

11. Palfreyman RW, Clark AE, Denton RM, Holman GD, Kozka IJ (1992) Kinetic resolution of the separate GLUT1 and GLUT4 glucose transport activities in 3T3-L1 cells. Biochem J 284: 275-281

12. Nishimura H, Pallardo FV, Seidner GA, Vannucci S, Simpson IA Birnbaum, MJ (1993) Kinetics of GLUT1 and GLUT4 glucose transporters expressed in Xenopus oocytes. J Biol Chem 268: 8514-8520

13. Clark AE, Holman GD (1990) Exofacial labelling of the human erythrocyte glucose transporter with azitrifluoroethylbenzoyl-substituted bismannose. Biochem J 269: 615622

14. Taylor LP, Holman GD (1981) Symmetrical kinetic parameters for 3-O-methyl-D-glucose transport in adipocytes in the presence and in the absence of insulin. Biochim Biophys Acta 642: 325-335

15. Whitesell RR, Gliemann J (1979) Kinetic parameters of transport of 3-O-methylglucose and glucose in adipocytes. J Biol Chem 254: 5276-5283

16. Simpson IA, Yver DR, Hissin PJ et al. (1983) Insulin-stimulated translocation of glucose transporters in the isolated rat adipose cells. Characterization of subcellular fractions. Biochim Biophys Acta 763: 393-407

17. Pedersen O, Hjollund E, Lindskov HO (1982) Insulin binding and action on fat cells from young healthy females and males. Am J Physiol 243:E158-E167

18. Cushman SW, Salans LB (1978) Determination of adipose cell size and number in suspensions of isolated rat and human adipose cells. J Lipid Res 19: 269-273

19. Kozka IJ, Clark AE, Holman GD (1991) Chronic treatment with insulin selectively down-regulates cell-surface GLUT4 glucose transporters in 3T3-L1 adipocytes. J Biol. Chem 266: 11726-11731

20. Kozka IJ, Holman GD (1993) Metformin blocks down-regulation of cell-surface GLUT4 caused by chronic-insulin treatment of rat adipocytes. Diabetes 42: 1159-1165

21. Yang J, Clark AE, Kozka IJ, Cushman SW, Holman GD (1992) Development of an intracellular pool of glucose transporters in 3T3-L1 cells. J Biol Chem 267: 10393-10399

22. Joost HG, Weber TM, Cushman SW (1988) Qualitative and quantitative comparison of glucose transport activity and glucose transporter concentration in plasma membranes from basal and insulin stimulated rat adipose cells. Biochem J 249: 155-161

23. Yang J, Holman GD (1993) Comparison of GLUT4 and GLUT1 subcellular trafficking in basal and insulin-stimulated 3T3-L1 cells. J Biol Chem 268: 4600-4603

24. Hissin PJ, Foley JE, Wardzala LJ et al. (1982) Mechanism of insulin-resistant glucose transport activity in the enlarged adipose cell of the aged, obese rat. J Clin Invest 70: $780-790$

25. Keller K, Strube M, Mueckler M (1989) Functional expression of the human HepG2 and rat adipocyte glucose transporters in Xenopus oocytes: comparison of kinetic parameters. J Biol Chem 264: 18884-18889 